$\begin{array}{ccccc} & \text { 無 } & \text { 顎 } & \text { 症 } & \text { 例 } \\ & & & \\ \text { 中野 } & \text { 友明・愛場 } & \text { 庸雅・久保 } & \text { 武志・山田 } & \text { 浩二 } \\ \text { 和田 } & \text { 匡史・鵜山 } & \text { 太一・福家 } & \text { 智仁 }\end{array}$

\title{
A Case of Agnathia
}

Tomoaki Nakano, Tsunemasa Aiba, Takeshi Kubo, Kouji Yamada, Tadashi Wada, Taichi Uyama and Tomohito Fuke

(Osaka City General Hospital)

\begin{abstract}
Agnathia literally means absence or severe dysplasia of the mandible. It is a rare expression of first brachial arch malformation. In the present case was detected polyhydramnios and the fetus demonstrated mandibular dysplasia on prenatal ultrasound diagnosis at 30 weeks of gestation. There were no signs of holoprosencephaly on prenatal MRI. At 36 weeks of gestation, cesarean section was performed. Immediately after birth the infant was tracheostomized. She has survived to infancy with tracheotomy.
\end{abstract}

Key words : agnathia, tracheostomy, polyhydramnios

\section{はじめに}

無顎症は第一鰓弓の発生異常による下顎骨の欠損と全 前脳症，内臓逆位などを合併する奇形で，新生児 7 万人 に1例ときわめてまれであり, ほとんどが周産期に死亡 する予後不良な奇形である ${ }^{1)}$. しかし, 中枢神経系奇形 の合併がなく, 出生時の㭔吸管理が成功した例では生命 予後は良好であると報告されており, 出生前診断の重要 性が示唆されている2). 今回われわれは出生前に無顎症 と診断でき, 出生直後に気管切開を施行し救命しえた 1 症例を経験したので報告する.

症例：生後 0 日, 女览.

\section{症例}

妊娠・出産歷：血族結婚ではない 32 歳の母親と 33 歳 の父親の第 1 子で，両親の家族歴・既往歴に特記すべき ことはなかった。 未熟卵体外受精胚移植法にて妊娠成立 した. 母親は妊娠 30 週に羊水過多にて当院産婦人科に紹 介された。胎児エコーにて下顎低形成を認めた。 妊娠 34 週時に MRI を施行し，無顎症，耳介低位および口蓋裂を 認めた（図1）。

\section{経 過}

重篤な中枢神経系の合併奇形がないため, 生命予後は 良好であると評価した，家族へ説明したところ，出生後 の積極的な児への治療を希望されたため, 胎児の成熟を 待ち帝王切開術の方針とした. 全身麻酔下にて体内治療 的帝王切開術を考慮したが，家族の同意が得られなかっ た. 平成 16 年 11 月 26 日, 妊娠 36 週 1 日で腰椎麻酥下 にて帝王切開を施行した. 児は肉眼的に著明な小顎, 耳 介低位, 口唇口蓋裂を認め, 出生前診断どおりの無顎症 であった（図 2)。児は婏出直後, 隣の手術室に移動し, 待機していた小児科医, 麻酔科医, 耳鼻科医によりファ イバースコープを用い気管内挿管を試みながら局所麻酔 下で気管切開を施行した。咽頭，喉頭の変形のため挿管 チューブは挿入できなかったが喉頭直上にチューブを留 置することで気道を確保でき，気管切開を施行し NICU 一搬送となった. 胎児婏出から気管切開にて気道確保す るまでに 15 分を要した. 児の体重は $1,838 \mathrm{~g}$, Apgar Score は 1 分值 3 点, 5 分値 4 点であった.

CTを施行したところ下顎骨は欠損していた (図 3). 他 の奇形としては唇裂口蓋裂, 右耳介奇形, 右外耳道閉鎖, 


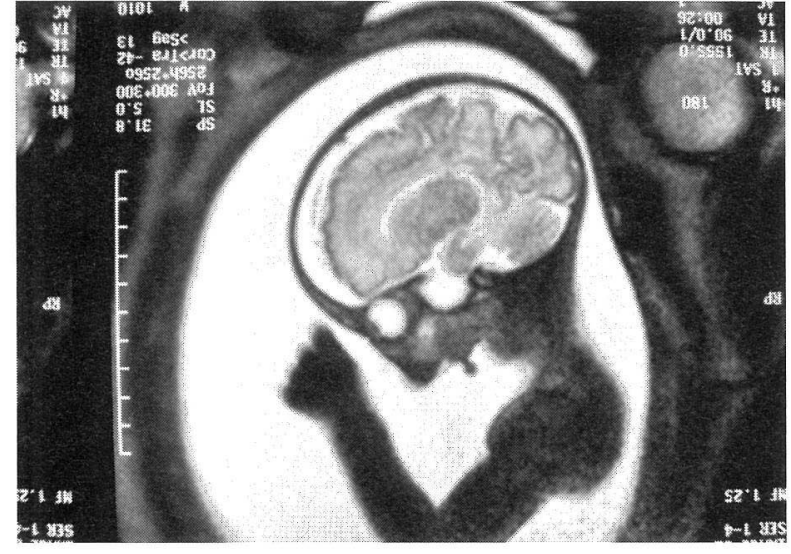

図 1 出生前 MRI 所見

左耳介低位，左外耳道狭窄，左上眼瞼皮膚欠損，椎骨の 異常 ( $\mathrm{C} 1$ 前弓欠損, $\mathrm{C} 3,4$ 右横突起癒合， C3，4，5 椎 体扁平化，C4，5，6 左横突起癒合，Th1-5 右横突起瘾合 等)を認めた。染色体検査は46XYの正常女性型であった。 生後 3 力月で $\mathrm{ABR}$ 老施行した。聴力は右 $90 \mathrm{~dB}$, 左 $60 \mathrm{~dB}$ であった。

考察

無顎症は, 胎生 4 週における神経堤細胞移動の異常に
より，下顎を形成する第 1 鰓弓の発生異常をきたすこと により発症すると考光られている31. そのため第 1 鰓弓 から発生する舌や耳の奇形とも関係する。

小顎を示す疾患は Robin Sequence, Treacher Collin's Syndrome など数多く, Jones ${ }^{4)}$, 梶井ら ${ }^{5)}$ は 65 の疾患を挙 げている，本症例には染色体異常がなかったことより， 染色体異常症を除き, 高度の小顎を呈する疾患をみると Roin Sequence, Treacher Collin's Syndrome, CerebroCosto-Mandibular Syndrome, Pena-Shkeir Syndrome など があるが，本症例はこれらの疾患の特徴を欠きいずれに も該当しないと考えられた。

無顎症は重症度により Leech ら ${ }^{6)}$ による分類があり, 1. 無顎症単独のもの, 2. 無顎症に全前脳症を伴うもの, 3. 無顎症, 内臟逆位, 内臓奇形を合併するもの，4．無 顎症に全前脳症, 内臟逆位を伴うものとしている. 全前 脳症や重篤な内臓奇形を伴うものでは生存例の報告はな いが，中枢神経系の重篤な合併症がみられない場合，予 後良好な症例むある7).

安里ら 2) によると無顎症 23 例の報告のうち 17 例は流 早産にいたっている. 全前脳症が 9 例, 中枢神経系異常 が 11 例に認めら机全例死亡の転帰をとっている.中枢神 経系異常のない 9 例では生存が 3 例あるが，いずれも出 生直後の蘇生とその後の呼吸管理が成功した症例であ

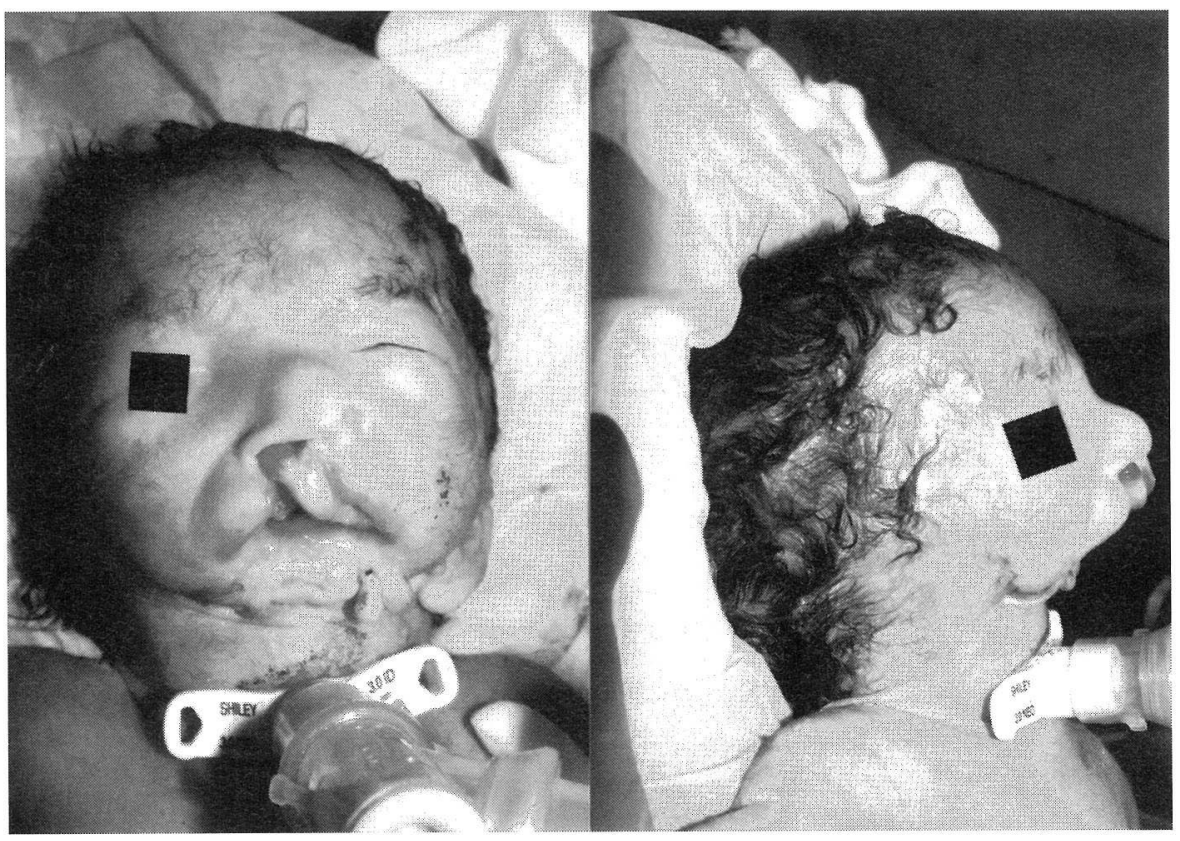

図 2 出生時顔貌 


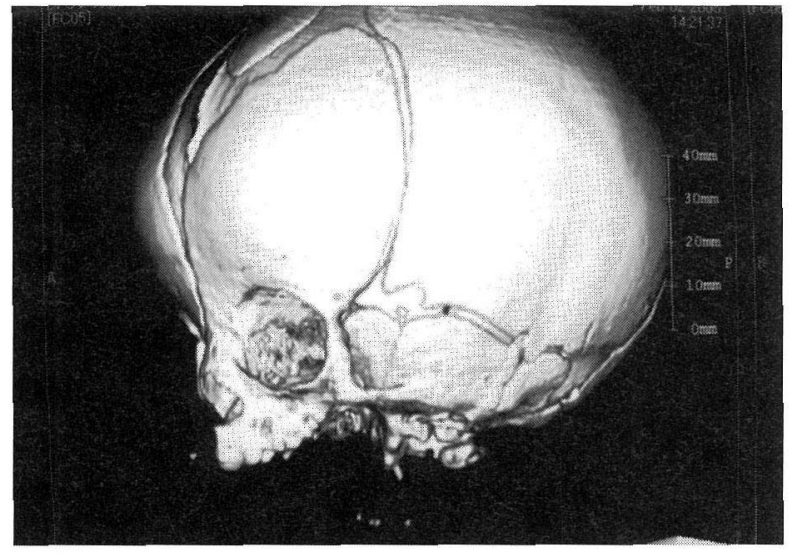

図 3 CT 所見

る. Kamiji ら ${ }^{8)}$ の報告では中枢神経系の合併奇形はなく, 5 歳時の発達は正常で, 病児保育所の生活にも適応して いると記載されている．このことから，無顎症は出生後 の呼吸管理が重要であると思われるため，出生前診断を 的確に行い中枢神経系異常の合併がなく家族が積極的な 出生後の治療を希望する場合, 出生直後の蘇生を円滑に 行う準備を整えておくことが重要である.

気管切開の手技としては小児の場合普通は全身麻酔下 で行うことが多いが，今回は局所麻酔下で動く患児を抑 えながら行らため困難であった。全身麻醉下にて体内治 療的帝王切開術の下で気管切開を施行した方が容易なよ らに思われた。

本疾患の胎児エコー所見で最も多く認められたのは羊 水過多症で 19 例中 11 例に認められた。 これは, 下顎骨 の欠如とそれに伴ら口腔咽頭筋群の欠損または低形成に よる讌下困難のため羊水循環の不均衡が起こり, 羊水過 多が発生していると思われる。次に多いのが無顎症また は小顎症の 4 例, 胃泡欠如の 4 例, 全前脳症の 2 例が認 められた2)7.

出生前に無顎症と診断できたのは 19 例中 4 例にすぎ ず，今後の診断率の向上が期待される.

\section{まとめ}

出生前に無顎症と診断でき, 出生直後に気管切開を施 行し救命しえた 1 症例を経験した. 中枢神経系異常のな い無顎症は出生時の呼吸管理が成功すれば良好な予後が 期待できるため, 出生前診断と出生時の蘇生が非常に重 要である。

\section{付 記}

本論文の要旨は第 293 回日本耳鼻咽喉科学会大阪地方連合会 （2005 年 6 月）にて発表した.

\section{参考文献}

1) Shermak MA and Dufresne CR : Nonlethal case of otocephaly and its implications for treatment. J Craniofac Surg $7: 372 \sim$ 375, 1996.

2）安里義秀, 佐久本薰, 屋良朝雄: 無靧症の 2 例. 日新生児 会誌 $37: 69 \sim 74,2001$.

3) Pauli RM, Graham JM and Barr M : Agnathia, situs inversus, and associated malformations. Teratology $23: 85 \sim 93,1981$.

4) Jones KL : Smith's recognizable patterns of human malformation. $4^{\text {th }}$ ed. W.B. Saunders Co, Philadelphia, 1988.

5）梶井 正, 黒木良和, 新川詔夫 : 先天奇形症候群アトラス. 南江堂, 東京, 1993.

6) Leech RW, Bowlby LS, Brumback RA, et al. : Agnathia, holoprosencephaly, and situs inversus: report of a case. Am J Med Genet $29: 483 \sim 490,1988$.

7) 須藤 敏, 與座朝義, 嘉数光雄, 他 : 出生時緊急気道確保 を要した奇形の 2 症例一先天性声門下狭窄症, 無顓症一. 小児耳 $25: 46 \sim 50,2004$.

8) Kamiji T, Takagi T, Akizuki T, et al. : A long surviving case of holoprosencephaly agnathia series. Br J Plast Surg $44: 386$ 389, 1991.

原稿受付：平成17年10月20日 原稿採択：平成17年11月30日 別刷請求先：中野友明 于534-0021 大阪市都島区都島本通2-13-22 大阪市立総合医療センター小児耳鼻咽喉科 